\title{
SER E NÃO SER GENTE: DINÂMICAS DA FEITIÇARIA NO ALTO XINGU*
}

\author{
Marina Vanzolini
}

Os afetos atravessam o corpo como flechas, são armas de guerra

(Deleuze \& Guattari 1997 [1980]:18).

Um conhecido mito de origem xinguano, do qual apresento aqui uma versão aweti, conta que os povos do alto Xingu, bem como os brancos e outras gentes que habitam o mundo atual, foram criados a partir das flechas confeccionadas pelos gêmeos demiurgos Sol e Lua para matar seu pai, a onça Itsumaret, e assim vingarem a morte de sua mãe, Tanumakalu, que havia sido morta por sua sogra jaguar. As flechas confeccionadas pelos demiurgos foram por eles transformadas em pessoas e, depois de efetuarem uma chacina na aldeia das onças, receberam dos gêmeos diferentes armas e utensílios, que se tornaram os artefatos distintivos de cada povo hoje existente. Sol queria que os índios recebessem as armas de fogo, mas estas eram tão pesadas que eles não puderam manejá-las, e preferiram tomar para si as bordunas e as flechas, deixando para os brancos as espingardas. Nessa mesma ocasião, os índios xinguanos receberam dos demiurgos o feitiço, tupiat, arma extremamente letal que, assim como a ausência das armas de fogo ou a presença de certos utensílios, tornou-se um distintivo desses povos. Não que os demais não tivessem adquirido seus próprios instrumentos de malefício mágico, mas adquiriram feitiços diferentes.

Sol e Lua, contam os Aweti, eram grandes feiticeiros. Ainda crianças, inventaram uma forma de atrair animais selvagens para destruir a roça de seu próprio avô, que lhes negava comida. Depois de grandes, tomados de ciúme, pois cada um acreditava que sua esposa o traía com o irmão, inventaram o feitiço "amarrado" e se enfeitiçaram mutuamente, por vingança. Por inveja, um sentimento identificado ao ciúme na língua aweti - temyzotu designa tanto o desejo de obter aquilo que pertence ao outro quanto o medo de perder aquilo que é seu — cada um enfeitiçou o filho do outro, e é por 
isso que os gêmeos demiurgos nunca puderem criar descendentes. Também enfeitiçaram suas lindas aves de estimação, das quais cada um cuidava como se fosse seu filho, de acordo com o costume xinguano.

O termo tomowkap, utilizado pelos Aweti para designar as histórias sobre as origens do mundo (e de fato qualquer história, antiga ou atual), indica que esses discursos devem orientar ou instruir, -mowka, nossos pensamentos e ações. O mito não impõe uma ordem ao mundo, mas ensina como as coisas um dia se passaram, e como provavelmente devem continuar a passar. Assim, tal qual se passa nas histórias dos antigos, os maus sentimentos entre parentes, frequentemente associados ao/à ciúme/inveja (temyzotu), continuam a ditar a lógica da feitiçaria xinguana até hoje.

Toda feitiçaria no alto Xingu provém de um outro xinguano — se de fato os outros, índios ou brancos, também possuem seus feitiços, o que não possuem são motivos para matar os xinguanos deste modo. Os xinguanos, aliás, eventualmente se apropriam dos feitiços tomados de outros povos contra seus próprios parentes: quando uma forma de gripe especialmente letal começou a assolar as áreas próximas ao Parque Indígena do Xingu, em 2009, muitos ali diziam que, se os xinguanos chegassem a se apoderar dela, iriam aniquilar uns aos outros com aquele feitiço de branco.

Ainda que qualifiquem a feitiçaria como um terrível mal do qual gostariam de se livrar, e ainda que muitas vezes oponham a figura dos feiticeiros à própria humanidade/moralidade pela qual se distinguem dos demais sujeitos que povoam o universo, os Aweti reconhecem a existência da feitiçaria entre eles como um aspecto tão antigo e inerente a seu modo de vida quanto o quarup, ritual funerário intercomunitário que, realizado pela primeira vez pelos gêmeos demiurgos por ocasião da morte de sua mãe, foi desde então o eixo central do sistema de trocas rituais que define as fronteiras do mundo social xinguano. Questionar as lógicas de funcionamento da feitiçaria xinguana pode ser, deste modo, um caminho para a compreensão de aspectos importantes do que significa, para os xinguanos, viver entre si, ser xinguano ou não sê-lo. É isto que proponho fazer aqui, a partir da etnografia dos Aweti, um grupo tupi xinguano. Esta reflexão ainda nos permitirá divisar uma dinâmica social xinguana - mas talvez não apenas xinguana, como procuro demonstrar ao longo do texto - que contradiz certas imagens do socius amazônico a partir de uma dialética entre construção interna de identidade e apreensão de potência diferenciante externa, ponto a que retornarei ao final. 
Os Aweti são um povo falante de língua tupi ${ }^{1}$ que habita a região das cabeceiras do rio Xingu, no nordeste do estado do Mato Grosso, no Planalto Central brasileiro. ${ }^{2}$ Hoje divididos em três aldeias localizadas à beira dos rios Curisevu, Tuatuari e Mirassol, os Aweti contam com uma população total de cerca de 250 pessoas, um número razoável se lembrarmos que, na década de 50, foram reduzidos a pouco mais de 30 indivíduos, sobreviventes das epidemias de catapora e sarampo que assolaram a região. Como seus vizinhos da área, vivem principalmente da pesca e do polvilho de mandioca brava. Ao lado de povos caribe (Kuikuro, Kalapalo, Nahukwá), aruaque (Wauja, Mehinaku, Yawalapití), tupi (Kamayurá) e do povo de língua isolada Trumai, os Aweti participam de uma intensa rede de trocas cerimoniais e matrimoniais, marcada também pelo compartilhamento de padrões éticos e estéticos, de um mesmo código de relações, e de um corpo mitológico que, como se viu, descreve a criação simultânea de todos aqueles povos pelos gêmeos Sol e Lua, com sua posterior diferenciação a partir da distribuição de distintas armas e artefatos pelos demiurgos.

Devido à dificuldade de navegação nos rios da região, a área dos formadores do Xingu permaneceu razoavelmente preservada da invasão colonial até meados do século XX, fato que provavelmente favoreceu a concentração ali de diferentes contingentes étnicos, cuja marcha em direção ao Brasil central não estaria desvinculada da fuga dos colonizadores. Os primeiros registros sobre os povos da área, datados das últimas décadas do século XIX, chamam a atenção para a uniformidade cultural que marcava o que já então se configurava como um sistema regional de trocas (Steinen 1940 [1886]). A constatação de tal uniformidade levou Eduardo Galvão (1979 [1953]) a distinguir a região como "área cultural do uluri" — nome dado em referência ao adereço pubiano feminino característico da ornamentação corporal xinguana. A partir de fins da década de 1970, uma preocupação em apontar o caráter histórico e processual do chamado sistema xinguano (ou sociedade xinguana) marca a etnologia regional (Menget 2001[1977]; Bastos 1989; Basso 1995; Franchetto \& Heckenberger 2001; Coelho de Souza 2001), que chamará também a atenção para a cristalização de suas fronteiras em decorrência da delimitação da área indígena no início da década de 1960 (ver sobretudo Bastos 1984/85, 1987/88/89, 1989).

Surgidos com essa literatura de viés histórico, relatos nativos sobre a integração ao regime sociocultural xinguano enfatizam a abdicação da guerra entre si como elemento central dessa passagem, também descrita nos termos nativos como um processo de tornar-se gente (Basso 1995; Coelho de Souza 2001). Como é comum a diversas línguas amazônicas, os Aweti utilizam um mesmo termo, mo'at, para designar tanto aqueles com quem compartilham 
um regime de valores e formas relacionais - todos os demais xinguanos quanto índios não xinguanos, brancos, animais e espíritos, nos casos em que se deseja enfatizar que estes vivem socialmente ou moralmente de modo similar ao xinguano, ou que possuem ou podem assumir forma humana. De abrangência contextualmente determinada, em suma, o termo aweti mo'at designa uma estética dos corpos e das relações, cuja marca principal é a adoção de um código moral pacifista. Neste sentido, ser gente, nos termos aweti, é não ficar bravo.

Mo'at, contudo, designa não apenas o mesmo xinguano, ente moral, mas também o outro xinguano que, por meio da feitiçaria, mata seus vizinhos. E como só se morre de feitiço no alto Xingu, toda morte é provocada por um xinguano que, pelo fato mesmo da vizinhança e da pertença àquela comunidade multiétnica, já é um parente. Enquanto entes não humanos provocam doenças nas pessoas atraindo seu duplo para viver perto de si, apenas a feitiçaria humana, geralmente realizada por coaldeãos ou gente de um mesmo grupo linguístico da vítima, provoca um adoecimento grave o suficiente para levar à morte. Uma forma alternativa de dizer que alguém foi morto por feitiço entre os Aweti é dizer que morreu mo'at 'angywo, "sob a sombra humana", isto é, devido à ação humana. Cada doença grave ou falecimento coloca em questão o caráter ambíguo ou instável da humanidade no alto Xingu: nunca se sabe quem é realmente gente por ali.

A constante afirmação de uma moral pacifista pelos xinguanos parece ser justificada pelo fato de que a identidade que fundamenta a abdicação da violência entre si nunca está plenamente garantida. Se os xinguanos jamais parecem ser completamente ou inequivocamente xinguanos para si mesmos, o universo humano/xinguano deve ser objeto de uma contínua constituição, o ser xinguano, produto de um contínuo esforço em permanecer xinguano. A feitiçaria fornece, desta forma, uma perspectiva a um só tempo "estrutural" e "histórica" da comunidade xinguana, que não existe senão nos intermináveis processos de tornar-se, deixar de ser ou manter-se xinguano.

\section{As armas do feitiço}

A principal matéria-prima do feitiço xinguano são flechinhas minúsculas que ora podem ser diretamente atiradas contra a vítima com um arco em miniatura que apenas os feiticeiros têm, ora amarradas a um resto de comida, parte corporal ou pertence roubado da vítima. Os Aweti afirmam que a técnica do lançamento de flechas (-'apit, "atingir") pode matar uma pessoa no espaço de algumas horas sem que ela sequer tenha conhecimento do 
que a fez adoecer, enquanto o feitiço amarrado age mais lentamente, e sua intensidade é passível de ser controlada pelo feiticeiro, que conversa com suas flechas orientando-as a agir rápida ou lentamente. Os feitiços amarrados (-ãtitu, "amarrado") — bolotas de cera de abelha com cerca de dois centímetros de diâmetro envolvidas por um fio de algodão — são geralmente escondidos perto da casa da vítima, junto a algum pequizeiro de seu quintal, por exemplo, ou mesmo dentro de sua casa, talvez sob o fogo de cozinha.

É comum os feiticeiros agregarem aos objetos contidos no amarrado algum material que confira qualidades específicas ao feitiço: palitos de fósforo e pele de cobra provocam coceiras e ardência; um pedaço de carne de cadáver pode causar gangrenas musculares e até paralisia; o pedaço de um fio elétrico atrairá um raio sobre a casa da pessoa que o feiticeiro quer atingir etc. Os usos e os efeitos de tais objetos, no entanto, não parecem seguir um código fixo, sendo antes matéria de improvisação e criatividade por parte do feiticeiro. As flechas de feitiço também podem ser misturadas à comida de uma pessoa (-poj, "alimentar", como se faz com um bebê ou animal de estimação) e, uma vez ingeridas, terão um efeito rápido sobre seu estado de saúde. Também se contam casos de feitiços que provocam problemas cutâneos quando atados a um adorno corporal da vítima, capazes mais tarde de se transformarem em enfermidades internas, como dores de barriga, febre, fadiga etc.

As flechas de feitiço podem ser genericamente designadas como flechas, $u^{\prime} w y p$, mas o termo específico que as distingue das armas comuns é tupiatsendo o feiticeiro referido como tupiat itat, "dono" ou "mestre" do tupiat. Restos de comida, roupas ou adornos corporais roubados da vítima para serem utilizados na amarração, bem como objetos que conferem qualidades específicas ao malefício, utilizados no feitiço amarrado, costumam ser referidos pelo mesmo nome. O termo tupiat é aplicável, ainda, a modalidades de malefício bastante distintas, que não envolvem flechinhas mágicas: são figurinhas antropomorfas ou zoomorfas moldadas geralmente em cera e madeira, utilizadas para atrair animais que comerão a roça da vítima, para atrair a alma penada de algum parente que levará o duplo de um vivente para a aldeia dos mortos no céu, ou mesmo para induzir diretamente a alma da vítima a viver entre animais na floresta.

Mais do que um tipo de objeto ou uma técnica específica, portanto, o termo tupiat parece designar o ato do malefício e seus meios, a ação com intenção de matar ou provocar o mal, e o veículo usado para tanto. Tal definição condiz com o significado da raiz tupi opi ou upi, muito provavelmente a mesma do tupiat aweti. Segundo o dicionário tembé-tenetehara de Boudin (1966:232), por exemplo, rupi seria uma posposição indicando o meio de 
uma ação qualquer, enquanto Betts (1981:195) registra para o parintintin que o substantivo upiar designa um objeto usado para causar a morte de uma pessoa ou animal, tal como aparece nas expressões pira upiar, armadilha para peixe, ou kunhano ndupiar, "objeto para matar uma mulher". Este último exemplo parece designar especificamente uma modalidade de feitiçaria na qual um objeto desejado pela vítima é utilizado como isca para atrair sua alma para junto do feiticeiro, técnica similar, aliás, àquela descrita por Vilaça (1992:158 e subs.) para os Wari' (txapacura) de Rondônia - o que atesta certa generalidade amazônica para o que vem sendo descrito, tema ao qual retornarei abaixo.

A raiz tupi $r$-opi aparece ainda nos termos que designam o guerreiro matador — brupiaré, moropi'hã e moropiarera — nas línguas aché, parakanã e araweté, respectivamente (Fausto 2001:304, nota 52), conexão que nos levaria a aproximar a feitiçaria xinguana à guerra em outros contextos tupi. Como se viu, contudo, a feitiçaria no alto Xingu não se dá entre inimigos, mas sim entre pessoas que se identificam pela adoção de uma ética pacifista entre si. É significativo, aqui, que os instrumentos utilizados para causar a morte entre os xinguanos - os feitiços, tupiat - sejam os próprios componentes corporais da pessoa, assim como as armas invisíveis que constituem o corpo de um vizinho-parente seu, caracterizando uma forma de interiorização das armas de guerra.

Disse que o substantivo parintintin upiar é aplicável ao objeto usado para a atração da alma por feitiço, enquanto o tupiat aweti abrange as extensões corporais roubadas da vítima pelo feiticeiro. Em ambos os casos, podemos dizer, a violência se dá por meio de algo que constitui ou virá a constituir a pessoa. Mas a feitiçaria não apenas requer a proximidade corporal entre feiticeiro e vítima, ela de certa maneira também a promove. O aparecimento da raiz opi no léxico xamânico waiãpi (Gallois 1996) pode fornecer uma pista a respeito do princípio de funcionamento do feitiço xinguano.

Formas diminutas dos espíritos auxiliares do xamã, que vivem em seu peito pendurados em pequenas tipoias, os opi-wan (sendo wan um sufixo coletivizador), são tanto seu escudo protetor quanto sua arma guerreira contra o ataque mágico de outros xamãs, causadores de todas as doenças que assolam os Waiãpi. A qualidade agentiva dessas armas xamânicas nos permite inferir que as flechas tupiat também são imbuídas de subjetividade, suposição que parece ser confirmada pelo fato de que seus donos falam com elas, orientando como devem agir - o que de resto, note-se de passagem, ocorre com qualquer caçador, que conversa com suas armas para que hajam como ele espera. A conexão linguística destes termos tupi nos sugere ainda, mais uma vez, que o tupiat xinguano pode ser pensado como transformação 
das armas guerreiras e xamânicas em outros contextos amazônicos, bem como das armadilhas de caça, agora transpostas para os corpos do feiticeiro e de sua vítima.

Apesar de os Aweti nunca terem se exprimido para mim explicitamente nestes termos, creio que podemos entender as flechas tupiat como componentes pessoais do feiticeiro, extensões corporais suas, do mesmo modo que os opi-wan são componentes subjetivados do xamã. Feitiço, em suma, é tanto um componente corporal da vítima quanto uma extensão corporal do feiticeiro; a feitiçaria efetivamente reúne - inserta ou amarra - esses corpos uns aos outros. Os feiticeiros xinguanos costumam caminhar sobre o túmulo de suas vítimas pois, segundo os Aweti, desejam saber se serão vitimados ou não pela feitiçaria de vingança (ver abaixo sobre esta técnica): caso o morto, de sua tumba, responda ao chamado do feiticeiro, a contrafeitiçaria será realizada com sucesso e o feiticeiro morrerá. Os Kalapalo (caribe xinguanos) teriam uma explicação distinta para o fato, que evidencia essa conexão física estabelecida através do feitiço: afirmam que o feiticeiro se acerca sorrateiramente do túmulo justamente em busca daquelas partes corporais suas que teriam ficado com o morto (Guerreiro 2011, comunicação pessoal). ${ }^{3}$

A especificidade da feitiçaria xinguana como agressão interna e criadora de proximidade se torna mais visível quando a comparamos com outras formas de agressão entre povos amazônicos. Mas a comparação também aponta, por outro lado, como se viu, a vizinhança entre o feitiço aweti e um xamanismo agressivo ameríndio. O dicionário tupi-guarani de Montoya traz mais um exemplo. Montoya traduz o termo tupichûa por "feiticeiro", mas explica se tratar do "dono" de um espírito familiar — um xamã, portanto. O autor sublinha, contudo, que a raiz rupi estaria associada às noções de "inimigo" ou "coisa ruim", indicando provavelmente que as potências não humanas associadas ao xamã guarani possam ser mobilizadas com fins de agressão e não apenas com finalidades curativas ou propiciatórias. Como o xamã waiãpi, o tupichua guarani seria a um só tempo curador e agressor, fato que a etnografia de Schaden (1974) e, mais recentemente, a de Pissolato (2006) confirmam.

Em face da coincidência entre as potências xamânicas e guerreiras em algumas culturas amazônicas e as armas do feiticeiro no alto Xingu, é preciso esclarecer de que modo o xamanismo xinguano se distingue claramente da feitiçaria, parecendo ter se despido ali das conotações guerreiras que o xamanismo assume em outros contextos amazônicos. ${ }^{4}$ Estas observações nos permitirão seguir delineando as transformações entre feitiçaria e guerra, violência interna e externa, e suas conexões com processos de aquisição de potência e construção de identidade nas culturas das terras baixas amazônicas. 


\section{Os riscos da identidade}

Assim como os feiticeiros, entes não humanos que povoam o universo xinguano, kat, possuem flechas microscópicas que lançam contra os humanos, quase sempre por ocasião de encontros fortuitos na floresta. Introduzidos em seu corpo, os pequenos projéteis, denominados kat u'wyp ou "flecha de kat", provocam o adoecimento da pessoa, frequentemente sob a forma de uma dor localizada ali onde ficaram alojados. A introdução das flechas de kat no corpo de alguém corresponde à separação entre seu corpo ('ô) e seu duplo ('ang), ${ }^{5}$ que passa a viver na aldeia do kat agressor (ver, para o caso wauja, descrição em Barcelos Neto 2004), e cuja ação é frequentemente atribuída, no entanto, não à vontade de fazer o mal, mas ao desejo de atrair o humano para perto de si. A presença das flechas de kat no corpo de uma pessoa é algo tão corriqueiro que remete menos a uma intenção qualquer, boa ou má, e mais ao fato de que a convivência sujeita os humanos ao constante risco de alteração por contaminação desses outros sujeitos com quem compartilham o espaço.

A principal atividade dos xamãs (mopat) aweti com quem convivi consistia em extrair por sucção tais flechinhas do corpo de seus pacientes, procedimento que corresponde ao retorno do duplo do doente para junto de seu corpo, e logo à sua reincorporação no universo dos parentes humanos. Como é comum a diversos povos amazônicos, o xamã xinguano recebe tanto de um iniciador quanto, mais tarde, de espíritos auxiliares as flechas que manterá dentro de seu corpo, cuidando para não perdê-las. O efeito esperado das flechas de kat no corpo dos xamãs é basicamente uma alteração perceptiva que confere ao humano a capacidade de ver e ouvir, num transe provocado pela ingestão de fumaça de tabaco ou em sonho, seu kat auxiliar (nemopat, "seu xamã", o xamã do xamã), que mostra ou conta ao xamã quem é o causador da doença de seu paciente.

Quando se trata de um ataque de kat, quase sempre basta extrair as flechas do corpo do doente, ${ }^{6}$ enquanto em caso de feitiço compete ao xamã encontrar, com a ajuda de seu kat auxiliar, onde foi escondido o amarrado preparado pelo feiticeiro, cuja identidade em geral resta desconhecida. Uma vez encontrado, o feitiço deve ser desatado e logo posto em água para esfriar, o que fará o doente recobrar sua saúde. Como registrei acima, o feitiço diretamente lançado contra a vítima não pode ser extraído pelo xamã, e costuma levar rapidamente à morte. ${ }^{7}$ Mas a participação do xamã curandeiro jamais tomará o sentido de uma contra-agressão, mesmo quando os ataques de kat são creditados ao envio de um feiticeiro humano mal intencionado que conduz o espírito agressor a se aproximar da vítima. Ao contrário do que 
se passa com os opi-wan waiãpi, ou com as flechas xamânicas em outros regimes nos quais a cura se confunde com a contra-agressão dirigida ao agente patogênico, as flechas dos xamãs xinguanos parecem conferir apenas a capacidade curativa, não sendo usadas como armas. ${ }^{8}$

O que interessa notar aqui é que, se qualquer pessoa pode ter flechas de kat em seu corpo como resultado dos deslocamentos suscitados por suas atividades diárias e dos inevitáveis encontros com kat, eventos que na maioria das vezes passam despercebidos, tais projéteis não são transmissíveis ou manipuláveis a não ser entre xamãs e, portanto, não se confundem com aqueles enviados intencionalmente pelo feiticeiro. O adoecimento por feitiçaria também se diferencia do adoecimento pelo contato com kat pelo fato de que qualquer tratamento contra o feitiço costuma ser inútil: os feiticeiros são reconhecidos por sua persistência, por nunca desistirem de atormentar suas vítimas, repetindo quantas vezes seja necessário o procedimento do malefício.

Os Aweti dizem que os aspirantes à prática da feitiçaria recebem suas flechas de um feiticeiro experiente, que pode ser ou não seu pai, e mais tarde costumam intercambiar entre si diferentes tipos de agentes malignos, tupiat. Para tornar a agressão efetiva e fazer com que os projéteis realmente machuquem a vítima, os feiticeiros devem recorrer a uma série de procedimentos com o intuito de fortalecer seu corpo, como se submeter a picadas de formiga tocandira ou queimar as palmas das mãos sobre as quais se ministrou seiva de copaíba, técnicas cujo efeito é deixar as mãos e os braços do feiticeiro mais "dolorosos" ou fortes (-taty-ka, "potencializar [a dor]"). Tais alterações corporais são correlatas àquelas sofridas pelo xamã em sua iniciação, quando têm flechas de kat introduzidas em seu corpo através do sopro do iniciador.

O que diferencia os xamãs dos feiticeiros no alto Xingu, portanto, não é tanto o fato de que os primeiros se constituem através da relação com entidades sobrenaturais, enquanto os segundos seriam praticantes de uma simples técnica, mas sim porque mobilizam potências não humanas distintas (cf. Lagrou 2004, para uma observação similar a respeito dos raizeiros e xamãs kaxinawá). Em todo caso, o ininterrupto processo de fabricação corporal pelo qual passam todas as pessoas no alto Xingu desde o seu nascimento deve ser entendido como uma sequência de alterações corporais produzidas pela introjeção de potências não humanas através de banhos, eméticos, adornos corporais, ervas esfregadas sobre a pele escarificada e mesmo a alimentação. ${ }^{9}$

O termo aweti kat parece designar menos uma classe específica de seres do que seu caráter indefinido. Em determinados contextos, kat significa 
apenas "coisa", e o termo provavelmente compõe a expressão karika tene (kat-ika tene), "uma coisa qualquer, sem valor". Num sentido mais estrito, o termo kat se aplica principalmente aos bens de valor utilizados nas trocas rituais (joro'jyt, prática mais conhecida na literatura pelo termo kamayurá moitará) constantemente realizadas entre comunidades locais, entre casas de uma mesma comunidade, ou mesmo entre moradores de uma casa. Kat pode ser entendido aqui como uma coisa que possui a capacidade de assumir um caráter subjetivo na condição de mediador de relações entre pessoas e, nesse sentido, os seres kat seriam uma manifestação especialmente potente dos entes não humanos do cosmos capazes de figurar de forma subjetiva em relações com humanos. Kat parece designar, em resumo, a potência subjetiva, agentiva, de um ente não humano qualquer. Isto nos permite entender os espíritos kat como entidades sem definição precisa, coisas que não sabemos exatamente o que são, dentre as quais os espíritos mais comuns do cosmos xinguano seriam aqueles sobre os quais sabemos exatamente que não sabemos o que são: kat. Fora isso, muitas coisas são potencialmente kat, à medida que podem interagir com as pessoas na condição de "espíritos", ou sujeitos não humanos.

A noção de "flechas de $k a t$ ", de forma correspondente, padece da mesma indefinição: quando um xamã diz haver extraído kat u'wyp de um paciente pode estar se referindo tanto às flechinhas dos espíritos com os quais o paciente entrou em contato, quanto a um resto da comida ingerida pela mãe de uma criança pequena, ou ao sêmen do pai que teve relações sexuais antes do período indicado e que, devido à intensa conexão física entre os progenitores e um filho ainda pequeno, estaria intoxicando o corpo da criança. No sentido mais genérico, portanto, kat u'wyp seria a projeção ou a extensão corporal transmitida por um ente qualquer a outro, contágio resultante de identidade física entre dois seres, no caso das relações de parentesco, ou produtor de identidade, no caso das relações com os espíritos kat. Lembremos que a introdução de flechinhas de espíritos no corpo de um doente é simultânea ao afastamento do duplo do doente para viver com kat, como parente.

Se as flechas de kat atingem os humanos produzindo identificação, o mesmo pode ser dito das flechas de feitiço que, no entanto, identificam feiticeiros com suas vítimas sem produzir uma nova sociabilidade para estas: seu duplo ficará vagando pelo espaço até que, separando-se definitivamente de um corpo então inerte (-'õ put, ex-corpo), seguirá para a aldeia dos mortos no céu. Deste modo, enquanto o ataque de kat é movido por um desejo de estabelecer laços sociais com os humanos, tornando-os congêneres desses outros sujeitos que são kat, o ataque do feiticeiro identifica sem produzir sociabilidade, e é movido simplesmente pela maldade, pelo desejo de agressão. 
A íntima conexão estabelecida através do feitiço entre o feiticeiro e sua vítima é comprovada pela feitiçaria de vingança, uma prática utilizada para matar, ou ao menos identificar os feiticeiros envolvidos na morte de uma pessoa. Única técnica de malefício considerada legítima no alto Xingu, a feitiçaria de vingança (ap'ut âtitu, "amarrado de ex-cabelo") é realizada apenas por alguns especialistas xinguanos, dos quais muitos dizem haver sido também feiticeiros, agora cansados de fazer o mal. A técnica utilizada é similar àquela da amarração na feitiçaria comum, mas desta vez empregamse partes do corpo da vítima - chumaços de cabelo ou um pedaço da pele da palma da mão do defunto - para atingir o feiticeiro. Seguindo a lógica do feitiço amarrado comum, formigas tocandiras são agregadas ao amarrado de cabelo ou pele do morto para conferir maior letalidade ao feitiço, logo pendurado sobre um fogo aceso com lenha especialmente espinhosa - mais um elemento a produzir dor no feiticeiro matador, já então designado $a p^{\prime} u t$ etsat, "aquele que é afetado por (amarrado de) ex-cabelo".

Espera-se que o feitiço de vingança provoque no feiticeiro violentas ondas de calor, incapacidade de ingerir alimentos comuns e desejo por alimentos crus ou excrementos, priapismo (ou ardência vaginal, no caso de o mandante do feitiço ser uma mulher ${ }^{10}$ ), zoofilia e finalmente a morte. É sabido, no entanto, que este fim é raramente alcançado, seja porque os feiticeiros contam com a medicina ocidental para controlar os efeitos da feitiçaria de vingança, seja porque os familiares da vítima não são suficientemente perseverantes para seguir por longo tempo as diversas restrições requeridas pelo contrafeitiço: a ingestão de alimentos doces ou de certas espécies de peixes e aves especialmente prolíficas (associadas à atividade sexual intensa), a prática sexual e mesmo o soar de uma simples risada, que adoçam ou amenizam a feitiçaria de vingança, fazendo-a perder o efeito.

Como se vê, na feitiçaria de vingança o corpo da vítima passa a operar como extensão corporal do próprio feiticeiro, conexão que se estende aos parentes da vítima, de tal modo que suas ações cotidianas tenham um efeito imediato sobre o matador. Assim como as flechas de kat identificam humanos e espíritos, uma vez reunidas aos ex-pertences da vítima ou diretamente introduzidas em seu corpo, as flechas tupiat têm como efeito uma espécie de consubstanciação ou identificação entre a pessoa atingida e o feiticeiro. Mas se ao aproximar suas extensões corporais (tupiat) àquelas da vítima (tupiat) o feiticeiro passa a controlar seu destino à distância, paradoxalmente se tornará também vulnerável pela conexão estabelecida através de sua flecha.

Tanto no processo de adoecimento decorrente de um encontro com kat quanto no adoecimento por feitiço, adoecer implica "aparentar-se" com outro. Tal processo é em tudo similar àquele da construção da identidade 
entre humanos através do compartilhamento de substâncias corporais e alimentos, mas também dos objetos de valor (kat), frequentemente doados entre parentes próximos para o pagamento das caras curas xamânicas. No entanto, mesmo a identidade do parentesco é perigosa, como demonstra o fato de a conexão extremada entre pais e filhos, nos primeiros anos de vida destes, responder por uma série de enfermidades que ameaçam a vida das crianças. Essa dupla faceta da identidade aparece com clareza nos múltiplos sentidos da noção mo'aká, "fazer tornar-se gente", ${ }^{11}$ expressão que designa a série de atos continuados de cuidado cujo efeito é produzir identidade entre pais e filhos após o nascimento destes. A expressão indica também a ação de alimentar animais de estimação para que, uma vez tornados mo'at, gente (ou, antes, iguais, "gente como a gente"), deixem de tentar fugir de seus parentes humanos adotivos. ${ }^{12}$

Quando aplicado a um bebê humano, contudo, mo'aka não designa apenas o processo de construção de identidade com os parentes humanos, mas também, ou sobretudo, a sobrevivência da criança nos primeiros meses de vida, nos quais está especialmente vulnerável a qualquer tipo de agressão, humana ou não humana, devido à intensa conexão que mantém com seus genitores. A mesma noção nos indica assim que, se a identidade com os pais e os demais parentes deve ser produzida, a consubstancialidade decorrente do processo de gestação cria o canal pelo qual a pessoa pode ser contaminada a qualquer momento, tornar-se outro, não humano. Esse risco é também sublinhado pelos Aweti quando explicam por que os gêmeos são seres extremamente frágeis, que nunca se tornam totalmente humanos (porque não sobrevivem aos primeiros anos de vida): devido à excessiva identificação entre eles, o que acontece a um afeta imediatamente o outro.

Tornar humano significa, em suma, garantir a existência parcialmente independente de um ser, e envolve ao mesmo tempo identificação e diferenciação ou separação. A noção de mo'aká revela que a identidade é necessária, mas perigosa, e deve ser controlada; revela também que o universo humano (ou dos congêneres), ainda que seja constituído pela identidade, não pode prescindir da diferença. A feitiçaria parece estar ligada a esta percepção. O feiticeiro é em geral alguém reconhecido como parente por sua vítima, e a própria feitiçaria é remetida às expectativas frustradas do feiticeiro, decorrendo, em última instância, da ausência de um compartilhamento esperado: tipicamente, o feiticeiro é um vizinho ciumento de algo que não lhe foi oferecido pelo outro, ou raivoso porque uma comida pedida lhe foi negada.

A identidade criada por meio do feitiço substitui, como pura negatividade, uma outra forma de aparentamento que falhou. Criar filhos e manter relações de parentesco, adoecer pelo contato com espíritos, ser vítima ou 
praticante de feitiçaria, cada uma destas ações envolve formas de identificação com efeitos distintos, mas sempre representando algum tipo de perigo. A mortal identificação entre o feiticeiro e sua vítima remete-nos ainda àquela gerada entre o matador de guerra e o inimigo morto, já amplamente explorada pela literatura americanista (cf. Albert 1985; Viveiros de Castro 1986; Sztutman 2005), e nos conduz novamente a uma consideração sobre as relações entre feitiçaria e guerra no alto Xingu e alguns outros contextos amazônicos, a fim de tentar situar melhor tanto as conexões pan-amazônicas do caso xinguano quanto a especificidade do feitiço como forma de agressão.

\section{Feitiço entre parentes: alguns casos amazônicos}

A feitiçaria de amarração xinguana remete a algumas técnicas de enfeitiçamento utilizadas por outros povos amazônicos, em contextos em que a feitiçaria ocorre preferencialmente, como no alto Xingu, entre aliados matrimoniais ou políticos, e não entre inimigos. Entre os Wari' (txapacura), como disse, a feitiçaria entre membros de um mesmo grupo local ou conjunto multicomunitário de aliados parece envolver uma técnica bastante similar à da feitiçaria parintintin (tupi) a que se refere Betts na explicação do termo ndupiar (Vilaça 1992:158-159; Betts 1981). Ainda podemos identificar essas técnicas com uma modalidade de feitiçaria encontrada entre os Kisêdje (jê), que consiste no envio da alma da vítima para junto da espécie animal associada a uma comida que o enfeitiçado teria negado ao feiticeiro (Seeger 1981:196 e subs., 1987). No caso kisêdje, a pessoa é capturada não por meio daquilo que foi seu ou daquilo que deseja, como se passa entre os xinguanos, os Parintin e os Wari', mas através de algo de que se apropriou avidamente recusando o compartilhamento.

Fazendo do próprio corpo da vítima o instrumento de sua morte, certas técnicas de feitiçaria parecem assim prevalecer em contextos em que o malefício é posto em movimento por relações entre pessoas próximas, de tal modo que aquilo mesmo que compõe pessoas através de relações passa a ser o meio de sua dissolução (ou alteração), e através das mesmas relações. Estes exemplos revelam sobretudo que a feitiçaria interna xinguana está longe de ser um caso isolado na Amazônia. A literatura amazonista das últimas décadas conferiu, no entanto, rendimento etnográfico e teórico muito maior às práticas de feitiçaria voltadas para fora do grupo social do feiticeiro, práticas frequentemente associadas à guerra (p.ex. Rivière 1970; Overing-Kaplan 1986). Vale a pena retornar, a fim de matizar tal imagem, 
à tese de Bruce Albert (1985) sobre os Yanomami da Amazônia brasileira, provavelmente a etnografia mais detalhada de que dispomos até o momento sobre feitiçaria na Amazônia.

Denominando-a "feitiçaria de guerra", Albert (:283) descreve a seguinte técnica utilizada pelos Yanomami para o ataque a um grupo inimigo: um grupo de homens arma uma emboscada nas imediações de uma aldeia longínqua, e ataca um transeunte solitário lançando sobre ele flechas envenenadas com o auxílio de uma pequena zarabatana. Tal expedição é designada pelo mesmo termo aplicado às expedições guerreiras, não havendo dúvidas de que esta forma de ataque é considerada pelos Yanomami uma técnica de guerra. Trata-se, portanto, de uma forma de agressão voltada para fora do grupo do feiticeiro, o que significa dizer, neste caso em particular, fora do conjunto multicomunitário de aliados periodicamente reunidos em rituais funerários. Resulta desta prática que, temendo sempre encontrar uma expedição de feiticeiros inimigos ao redor de suas aldeias, os Yanomami tomam diversas precauções para se protegerem, evitando afastar-se de casa sozinhos ou perambular à toa durante a noite. Nisto se pareceriam com os xinguanos, sempre atentos aos menores ruídos noturnos, os quais muitas vezes interpretam como sinais de comunicação entre feiticeiros, produzidos com pequenas flautas de ossos animais. ${ }^{13}$

O fato de os Yanomami e os xinguanos compartilharem o mesmo medo de emboscadas de feiticeiros distantes indica que uma feitiçaria de guerra semelhante àquela praticada pelos Yanomami ocupa um lugar paradigmático no ideário xinguano, ainda que este raramente se confirme nos casos de enfeitiçamento. Mas a recíproca também é verdadeira: a feitiçaria entre parentes que caracteriza o regime xinguano não parece estar completamente fora do quadro de possibilidades da agressão entre os Yanomami. Em outras palavras, se a feitiçaria interna xinguana tem a guerra como modelo, e tem como figura paradigmática um feiticeiro vindo de longe, a feitiçaria de guerra yanomami pode também resvalar para agressão interna, como se verá.

Uma diferença crucial entre os dois sistemas deve, contudo, ser notada: mesmo quando o feiticeiro xinguano é um desconhecido, trata-se de um outro xinguano, ou seja, um membro de um conjunto de grupos aliados cuja identidade é periodicamente reafirmada, como se passa também periodicamente entre os aliados yanomami na prestação mútua de serviços funerários. Albert afirma que os casos de feitiçaria ocorridos no interior do conjunto multicomunitário de aliados yanomami nunca são letais (:239 e subs.), mas sua própria etnografia deixa entrever que as coisas não se distinguem com tanta clareza. Pois, como enfatiza diversas vezes o autor, as relações de aliança e inimizade entre grupos yanomami não são estáveis, 
e os limites do que seja interno ou externo ao conjunto multicomunitário de aliados nem sempre estão claros (:195, 213, 358, 507, p.ex.). Acusações mútuas de feitiçaria, envenenamentos e convites rituais que na verdade preparam emboscadas de vingança, quando um grupo acredita ter sido vítima de feitiçaria, não seriam incomuns entre aliados, sobretudo aqueles em processo de aproximação recente. A dinâmica das alianças intergrupais yanomami nos permite pensar, pois, que a distinção entre as diferenças internas no socius xinguano e aquelas entre os conjuntos multicomunitários yanomami e seus inimigos seria antes de grau do que de natureza.

O ritual funerário do quarup ${ }^{14}$ e outros rituais intercomunitários xinguanos se, por um lado, reafirmam periodicamente o compartilhamento de um mesmo código estético e moral, por outro, recriam ao mesmo tempo as diferenças entre os grupos locais/étnicos, que se apresentam como adversários na luta do huka-huka, fechamento necessário de todos os encontros entre grupos aliados. No quarup é encenada, na primeira noite da fase intercomunitária do ritual, uma invasão da aldeia anfitriã por cada um dos grupos convidados, que saem alternadamente de seus acampamentos localizados nas imediações da aldeia convidadora. Responsáveis pelo definitivo afastamento dos mortos, tais aliados-inimigos são necessários para o bom funcionamento do cosmos e, nesse sentido, o ritual cria um contexto não só para a reafirmação periódica da identidade que define a comunidade xinguana, mas também para a recriação das diferenças entre grupos.

No entanto, as boas diferenças que o ritual regenera podem também engendrar as más diferenças que a feitiçaria implica: o jaguar é, de fato, a figura prototípica tanto do feiticeiro xinguano, que vem de longe atacar vestido com sua roupa animal, quanto dos campeões de luta, que enfrentam adversários de outras aldeias em disputas nem sempre tão pacíficas e esportivas como se esperaria. Na mitologia xinguana, o perdedor na luta é literalmente devorado por seu adversário jaguar. O uso de rezas secretas para enfraquecer o oponente no huka-huka é tão comum quanto mal visto entre os xinguanos. E não raras vezes, uma luta termina em acusações de deslealdade entre os grupos dos lutadores. ${ }^{15}$ Estas imagens não deixam que se perca de vista totalmente, para os xinguanos, o fato de que um aliado é sempre um possível feiticeiro.

A descrição de Vilaça (1992) sobre a dinâmica ritual dos Wari' talvez nos permita identificar uma associação entre feitiçaria interna e diferenciação intergrupal reproduzida ritualmente, semelhante à que encontramos para 0 caso xinguano. A feitiçaria wari' ocorre no interior de um conjunto de aliados reunidos em torno de ritos funerários nos quais os afins reais corresidentes devem desempenhar o papel de devoradores do cadáver — desempenham 
uma função-Outro, por assim dizer. Permitindo uma diferenciação desejada entre os parentes do falecido e seu cadáver através dos afins corresidentes, o ritual produz também, a contrapelo, uma diferenciação entre corresidentes wari' através do cadáver. Ainda que a etnografia wari' privilegie seu caráter benéfico, seria talvez legítimo relacionar tal produção de alteridade entre corresidentes, que em outro contexto se tratam como consanguíneos, a uma feitiçaria voltada para dentro, distinguida da agressão aberta guerreira.

Ora, o rito funerário yanomami, assim como os ritos xinguano e wari', só confirmam a identidade entre grupos aliados reafirmando, simultaneamente, sua diferença, ao opor aqueles que choram àqueles que devoram as cinzas do cadáver (não corresidentes e afins classificatórios corresidentes). Tudo leva a crer que os regimes de violência wari' e xinguano não estão em total descontinuidade com o sistema de agressões yanomami. Restaria averiguar se este último registra formas letais de violência interna, como se passa nos demais.

De fato, uma modalidade de feitiçaria yanomami, o feitiço "por roubo de pegada" (par prise d'empreinte), situa-se a meio caminho entre a feitiçaria praticada por aliados não corresidentes, na qual são empregados venenos esfregados na pele da vítima ou misturados à sua comida, e a feitiçaria ou xamanismo de guerra entre grupos inimigos, envolvendo o envio de espíritos agressores a aldeias distantes (no xamanismo de guerra) ou, como se viu, a organização de expedições de guerreiros-feiticeiros (Albert 1985:237 e subs.). Como indica o nome, a matéria-prima do feitiço por roubo de pegada, remetendo àquela utilizada no feitiço amarrado xinguano e às diversas técnicas de feitiço que vimos envolver proximidade entre o matador e sua vítima, é a terra marcada pelos passos da vítima ou qualquer pedaço de um pertence seu, como a ponta de um cigarro.

Assim como a feitiçaria comum e a feitiçaria amorosa yanomami, ambas envolvendo o uso de venenos, a feitiçaria por roubo de pegada ocorre entre membros de grupos locais aliados mas, diferente daquelas, esta costuma ser letal, e portanto é vista pelos Yanomami com tanta seriedade quanto a feitiçaria praticada por inimigos. É ainda importante notar que essa técnica envolve sempre a participação de um especialista proveniente de um grupo inimigo: a terra sob a pegada ou outro objeto é roubada(o) por um aliado da vítima, mas o feitiço mesmo é realizado por alguém de um grupo não aliado, geralmente, o aliado de um aliado. A ocorrência de tal modalidade de feitiço evidencia, assim, o fato de que os aliados nunca são absolutamente confiáveis, na medida em que abrem espaço para o acesso de inimigos ao interior do grupo local. ${ }^{16}$

Ainda seguindo a descrição de Albert, vemos que feitiçaria por roubo de pegada yanomami não ocorre, contudo, apenas entre grupos locais aliados, 
mas também dentro de um mesmo grupo local, ou seja, entre aliados por casamento ou consanguíneos (1985:270). Na maioria dos casos, homens recém-casados, vivendo uxorilocalmente, são acusados de enfeitiçar seus novos corresidentes; mas também seriam frequentes os casos em que excorresidentes enfeitiçariam uma mulher casada virilocalmente. É evidente que, se os casamentos exogâmicos feitos por membros de um grupo local são responsáveis pelo estabelecimento de laços políticos essenciais para a manutenção deste (os aliados são sobretudo aliados de guerra), tais casamentos são também o meio de entrada de estrangeiros, idealmente aliados mas potencialmente inimigos, no seio da comunidade. É notável que essa modalidade de feitiçaria ocorra entre afins reais, identificados com os consanguíneos nos rituais funerários intercomunitários. Neste caso, não é a distância e o desconhecimento entre inimigos que produzem atrito, como na guerra, mas a própria proximidade. Por outro lado, a mulher casada, longe de casa, pode tornar-se inimiga para seus ex-parentes. Dinâmicas que, combinadas, revelam certa propensão à diferenciação: é mais fácil tornar-se inimigo casando fora que se tornar parente casando dentro.

Assim como a morte na guerra, a feitiçaria yanomami é pensada como devoração e, do ponto de vista yanomami, não parece haver diferença entre estas duas formas de agressão: após a morte da vítima, o feiticeiro yanomami deve passar pelo mesmo ritual do matador de guerra, pois seu corpo está impregnado pela carne apodrecida e o sangue do cadáver, que devem ser eliminados através da ingestão continuada de eméticos (Albert 1985:342). É possível que, como parece ser o caso xinguano, a feitiçaria praticada em diversas culturas amazônicas possa ser descrita como uma forma de aproximação ou fusão entre o feiticeiro e sua vítima. Técnicas de feitiçaria de vingança muito similares àquela praticada no alto Xingu são empregadas, por exemplo, pelos Piaroa (Overing-Kaplan 1986) e os Warao (Wilbert 2004), povos caribe das Guianas, e pelos Baniwa, aruaque do rio Negro (Wright 2004), e parecem confirmar essa suposição. Entre os Warao, o fato de que o feitiço estabelece uma conexão física entre o feiticeiro e sua vítima, uma forma de aparentamento, é ainda confirmada pelo fato de que o sangue do morto é conduzido, por intermédio do corpo do feiticeiro, a deuses araras canibais.

A etnografia de Albert descreve, como se viu, de que modo técnicas distintas de agressão atravessam diversos níveis de relação entre os Yanomami, podendo ser usadas ora como arma de guerra entre inimigos instituídos, ora desfazendo alianças instáveis entre grupos, ora desfazendo alianças interpessoais dentro dos grupos. As práticas de envenenamento, aparentemente difundidas em toda a Amazônia, apontam para uma dinâmica semelhante, sendo utilizadas em relações quase sempre marcadas pela ambivalência entre 
aliança e inimizade. Entre os Yanomami, o veneno de pelo de macaco seria utilizado contra inimigos, despejado durante a noite por uma expedição de feiticeiros-guerreiros nos recipientes de comida da casa atacada, mas também contra aliados políticos com os quais as relações amistosas fracassaram por algum motivo, sendo então despejado na bebida oferecida aos convidados para um ritual intercomunitário (Albert 1985:291).

Chaumeil (1983:226 e subs.) também registra para os Yagua, povo caribe da Amazônia peruana, e Gallois (1996) para os Waiãpi, tupi do Amapá, o costume de convidar inimigos para reuniões intercomunitárias, na verdade emboscadas nas quais se servirá bebida envenenada. Entre os Yagua, tais eventos seriam ainda uma ocasião privilegiada para a execução de xamãsfeiticeiros, atraídos para a armadilha quando responsabilizados por terem matado, enviando seus espíritos xamânicos, alguém do grupo anfitrião (Chaumeil 1983:62). As vítimas de envenenamento são, nestes casos, antes ex-afins ou quase aliados do que simplesmente inimigos. Casos de envenenamento também são frequentes no alto Xingu, onde por vezes se teme que mesmo a comida oferecida entre coaldeãos ou afins de aldeias distintas venha "misturada com feitiço", tupiat eze. Está claro, enfim, que as diversas formas de agressão - guerra aberta, feitiçaria, envenenamento alimentar — compõem um contínuo dinâmico em que não há inimigos claros, mas tampouco, ou sobretudo, amigos evidentes.

Um famoso caso de enfeitiçamento no alto Xingu, envolvendo um homem aweti executado sob suspeita de ter envenenado o jovem amante kamayurá de sua filha, me parece ilustrativo de um aspecto central da feitiçaria ali. A execução do suposto feiticeiro a caminho de uma pescaria coletiva foi considerada por muitos aweti como uma terrível injustiça: dizem que o jovem kamayurá foi na verdade enfeitiçado por gente de sua própria aldeia, mas o aweti, levando a culpa, foi quem acabou pagando com sua vida. Talvez seja a impossibilidade mesma de determinar com segurança sua origem que confere ao feitiço a potência de converter-se em uma arma voltada contra o próprio grupo, sua força de desestabilização, seu caráter de máquina de guerra, constantemente impedindo a estabilização de coletivos claramente definidos ${ }^{17}$ (Deleuze \& Guattari 1997 [1980]).

\section{Sociedades para-a-guerra e o intervalo do feitiço}

Como se viu, a terminologia aweti empregada na feitiçaria a inscreve no campo da guerra, do xamanismo e da caça, formas de relação com a alteridade humana e não humana centrais no processo de constituição de 
corpos individuais e coletivos na Amazônia, como vem sendo demonstrado na etnologia americanista desde a década de 1980 (cf. Taylor 1994; Viveiros de Castro 1986, 1993; Fausto 1999, 2001; Vilaça 1992; Sztutman 2005). O fato de potências exteriores ao socius desempenharem um papel constitutivo na formação de pessoas singulares e coletivas se evidencia, no universo xinguano, nas práticas xamânicas de cura.

Como demonstra Barcelos Neto (2004) em sua etnografia dos Wauja (aruak xinguanos), o xamanismo xinguano consiste numa máquina de conversão da atração exercida pelos espíritos patogênicos sobre os humanos cujo adoecimento reflete um afastamento do duplo para viver entre os não humanos - em atração dos espíritos pelos humanos, patrocinadores de rituais nos quais os espíritos dançam e comem na aldeia xinguana. Mais do que isso, o processo de cura através da realização de rituais permite a criação de coletivos humanos em torno de chefes patrocinadores de ritos e especialistas rituais - atração de seguidores pelos chefes através dos espíritos. Mas o pensamento xinguano, como se viu, distingue claramente feitiçaria e xamanismo. O que importa sublinhar aqui é que a feitiçaria xinguana, dissociada das atividades curativas xamânicas, não pode operar como um instrumento relacional produtivo, e revela-se inversamente como efeito de convivência com uma identidade potencialmente perigosa. Enquanto o xamanismo, a caça e a guerra põem em marcha uma relação socialmente criativa com potências exteriores ao socius, a feitiçaria entre parentes aponta para uma aparição descontrolada da alteridade no interior das relações de identidade.

O vínculo entre guerra e feitiçaria é um tema recorrente da xinguanologia, já que, como muitos etnólogos notaram, a abdicação da hostilidade aberta entre xinguanos nunca representou o desaparecimento da violência naquele universo. Ao analisar a conexão entre estas duas formas de agressão, Thomas Gregor (1992) sustenta que a feitiçaria desempenha um papel positivo na afirmação da moralidade antibelicista xinguana, pois o medo da acusação de feitiçaria, sugere o autor, levaria os xinguanos a agir sempre moralmente (ver também Dole 1964, 1976 e Zarur 1975, autores com hipóteses similares). A tese é problemática em diversos aspectos. Primeiro, ela só poderia ser verdadeira se houvesse algum tipo de consenso em relação à identidade dos feiticeiros xinguanos, coisa que não se verifica na etnografia do próprio Gregor. Será, pois, sempre complicado definir segundo quem é que se deve agir moralmente. Segundo, se de fato o medo da acusação operasse com eficiência um controle moral no alto Xingu, seria esperado que fossem raras as acusações de enfeitiçamento ali, o que tampouco se verifica.

A hipótese de que a ameaça de feitiço teria um efeito apaziguador naquele universo relacional é desmentida, enfim, pelo fato notório de que 
as acusações de feitiçaria levam a um movimento contínuo de fissões das aldeias, observável atualmente sobretudo entre os grupos mais populosos que habitam as margens do rio Culuene. Mais do que isso, os Aweti muitas vezes demonstram ver as acusações de feitiçaria como um acontecimento tão grave quanto a própria feitiçaria - a ponto de alguns terem me explicado que a convivência com uma família que terminou se mudando da aldeia tornara-se insuportável em função de seus membros não pararem de acusar os demais aldeãos de enfeitiçamento. Não parece plausível, como sustenta Gregor, que a feitiçaria seja uma faceta operacional da moralidade pacifista xinguana, e como tal uma marca das fronteiras desse coletivo marcado pela eliminação da guerra de seu interior.

Propondo uma análise alternativa à de Gregor, Coelho de Souza (2001) sugere que a feitiçaria xinguana seria o meio de abertura do universo xinguano ao exterior, permitindo que grupos inicialmente estranhos fossem integrados àquela rede relacional de tal modo que sua alteridade fosse percebida não mais sob a forma de uma ameaça guerreira, característica da inimizade aberta entre inimigos, não xinguanos, mas como ameaça de feitiço, característica da inimizade latente entre parentes, xinguanos. A feitiçaria representaria o caráter negativo, perigoso, da introjeção dos outros numa rede de relações que supõe identidade, mas também requer a manutenção de um coeficiente de diferença como condição de possibilidade para as trocas cerimoniais e matrimoniais. O feitiço seria, assim, uma forma de resíduo do processo necessariamente incompleto de tornar-se mesmo xinguano. Esta análise é consistente com grande parte dos discursos nativos sobre a feitiçaria no alto Xingu, já que em comentários genéricos os xinguanos sempre apontam os outros como feiticeiros, ainda que sejam outros xinguanos. É compreensível, assim, que grupos recém-integrados ao regime pacífico de trocas que define o pertencimento ao universo xinguano tendam a ser responsabilizados pelos casos de morte atribuídos ao enfeitiçamento.

Mas, como vimos, a feitiçaria xinguana é detonada pelo processo mesmo do parentesco, isto é, surge nas interações cotidianas através das quais as pessoas se afirmam como parentes ou não. Neste caso, estaria mais associada a uma constante produção interna de inimizade do que à internalização do inimigo ao longo da história. Não é suficiente, pois, ainda que não seja falso, dizer que a feitiçaria é uma continuação da guerra por outros meios, uma guerra mascarada pela vigência de uma moral pacifista. Trata-se mais de uma irrupção da violência a partir do centro da vida social, uma guerra constantemente produzida pela própria dinâmica do parentesco. A feitiçaria entre parentes, em suma, é mais uma forma pervertida da guerra do que uma guerra invisível ou internalizada. 
Esta descrição talvez não represente novidade em relação a outros regimes sociocósmicos na África ou na Oceania (cf. Evans-Pritchard 2005 [1937]; Middleton \& Winter 1963; Douglas 1970; Kapferer 1997; Stasch 2001, 2009), mas é menos recorrente na literatura amazonista, na qual o tema tem sido pouco explorado tanto em descrições etnográficas quanto em análises de suas implicações e pressupostos cosmológicos e políticos. A ausência talvez se deva à polarização temática à qual tendeu a etnologia regional, preocupada ora com a reprodução intracomunitária de identidade, ora com as relações de predação voltadas para o exterior do socius, deixando de lado uma endoviolência que atravessa os dois polos, marcando um movimento de produção interna de alteridade, geralmente vista pelas pessoas nela envolvidas como puro horror e negatividade. Acima de tudo, tal dinâmica parece contradizer uma imagem corrente do socius amazônico como corpo coletivo oposto a outros coletivos de mesma natureza por relações belicosas, mas internamente homogêneo ou dedicado a um constante processo de homogeneização.

Porém, um olhar mais atento para a feitiçaria pode revelá-la como resultante desse mesmo projeto de identificação que move os coletivos, projeto que estará sempre ainda por realizar. A feitiçaria demonstra, enfim, que não há pacificação sem produção de violência, o que nos remete à formulação de Viveiros de Castro (2002) sobre o parentesco ameríndio como um processo de construção de identidade a partir da diferença, processo fadado à incompletude: todo feiticeiro é um ex-parente precisamente porque a inimizade é a forma básica ou primeira de toda relação para estes povos ameríndios, de forma que todo parente é potencialmente inimigo. ${ }^{18}$

É importante notar ainda que não parece ser possível traçar aqui uma distinção nítida entre sociedades atravessadas por facções nas quais proliferaria a violência interna - caso, por exemplo, dos Jê do Planalto Central (p.ex., Maybury-Lewis 1974 [1967]) e dos xinguanos — e sociedades da floresta internamente homogêneas, como os Piaroa ou Yanomami, entre os quais a agressão mágica apareceria principalmente associada à guerra. Como se viu, ligadas ou não à atividade xamânica, práticas de agressão mágica entre pessoas próximas aparecem em grupos de morfologias muito variadas (cf. Schaden 1974 e Pissolato 2006, para os Guarani; Seeger 1981, para os Kisêdje etc.), e mesmo os casos yanomami e yagua devem ser matizados, já que os limites entre dentro e fora do socius nunca estão perfeitamente claros ou estabilizados.

É evidente que nos grupos de composição menos rígida os atritos da vida diária podem se resolver mais facilmente com a simples separação dos descontentes, enquanto sistemas mais estáveis comportam diferenças e tensões internas por mais tempo. Como nota Rivière (1970) a respeito dos Trio das Guianas, antes mesmo de uma acusação de feitiçaria tornar-se pública, 
é provável que os acusados decidam mudar de aldeia e, deste modo, toda feitiçaria provém senão a priori, a posteriori, de fora. A diferença entre tais sistemas reside, pois, na variação de velocidade das dinâmicas de aproximação e distanciamento, identificação e diferenciação.

Reconhecer a produção de diferença engendrada no processo cotidiano de criação de identidade nos permite entender, desde um ponto de partida complemente distinto, aquilo que Clastres apontou como filosofia contra-oEstado das sociedades amazônicas, já que, como motor de fissão das unidades sociais, a feitiçaria impede a cristalização de coletivos, logo, de ordenações hierárquicas intra e intergrupais. Talvez os xinguanos, frequentemente tomados como exemplo da presença de organizações hierárquicas na Amazônia, e os Yanomami, imagem perfeita da sociedade-para-a-guerra de Clastres (2003 [1974], 2004 [1977]), não sejam tão diferentes assim. Ou talvez, guardadas as enormes diferenças entre essas formas sociais, elas sejam aproximadas justamente pela presença da feitiçaria em ambos os universos.

Em diversas sociedades amazônicas, a feitiçaria parece assim operar uma transição entre a guerra propriamente dita e uma guerra não propriamente interna, mas capaz de tornar indefiníveis as fronteiras entre o dentro e o fora. Se os valores atribuídos a estas duas formas de violência pelas pessoas que as vivem são radicalmente diferentes, seus efeitos não deixam de ter correspondência: manutenção da autonomia de coletivos, resistência a sistemas políticos globalizantes. Não se trata aqui de apontar um lado positivo do feitiço xinguano, o que implicaria um completo afastamento do que pensam os xinguanos sobre o assunto, mas sim entendê-lo como aspecto inerente a seu modo de ser, lado obscuro de uma forma de vida que tem na afirmação da diferença e da autonomia um valor fundamental. O medo do feitiço é acima de tudo o medo da influência que os outros, aos quais se está fisicamente ligado através das trocas geradas na vida cotidiana, podem exercer sobre nós. O medo da identidade excessiva é o mesmo que o medo da irrupção de uma diferença que nunca desaparece, da mesma forma que se passa com os gêmeos, jamais plenamente identificados entre si.

Recebido em 10 de abril de 2012

Aprovado em 06 de agosto de 2013

Marina Vanzolini é doutora em Antropologia Social pelo Museu Nacional, UFRJ, e professora da Universidade de São Paulo. E-mail:<marinavanzolini@ gmail.com> 


\section{Notas}

* O argumento central deste artigo foi desenvolvido em minha tese de doutorado, A flecha do ciúme: o parentesco e seu avesso segundo os Aweti do Alto Xingu (Figueiredo 2010). Ele se baseia numa pesquisa de campo de cerca de 12 meses, desenvolvida entre 2006 e 2010, na aldeia Tazu'jyt, também conhecida na região como Aweti. A pesquisa que deu origem a este trabalho foi possível graças ao apoio do PPGAS-Museu Nacional/UFRJ, dos projetos Nuti-Pronex “Transformações Indígenas: os regimes de subjetivação ameríndia à prova da história" (Faperj-CNPq, 2004-2006) e "Ontografia comparativa e equivocação controlada" (CNPq, 2008-2011), bem como de bolsas de estudo concedidas pela Capes (2006-2008) e pela Faperj (2008-2009, 2010-2011-PAPD). Agradeço a Eduardo Viveiros de Castro, Marcela Coelho de Souza, Renato Sztutman, Aparecida Vilaça e Bruna Franchetto pelos comentários sobre a tese, e a Julia Sauma pela leitura atenciosa deste artigo

${ }^{1}$ Próxima ao saterê-mawé e às línguas da família tupi-guarani, a língua aweti foi recentemente classificada como parte de um ramo "maweti-guarani", do qual teriam se desenvolvido, por um lado, as línguas T-G e, por outro, as línguas saterê-mawé e aweti (Drude 2006).

2 Trata-se da área meridional do Parque Indígena do Xingu (PIX), criado em 1961 como Parque Nacional do Xingu e convertido em área indígena em 1967 (cf. http://pib.socioambiental.org/pt/povo/xingu/1539). No curso médio do Xingu, o PIX abrange ainda a área ocupada pelos Ikpeng (caribe), Yudjá e Kajabi (tupi-guarani), Kisêdje e Tapayuna (jê), povos que não participam, ou não da mesma maneira que os povos da parte sul do Parque, do sistema de trocas que caracteriza a região cultural do alto Xingu.

${ }^{3}$ Segundo Wilbert, os feiticeiros warao costumam andar sobre o túmulo de suas vítimas após o enterro criticando-as por terem sido sovinas com sua comida e seus bens. O fato é curioso, pois o ataque de feiticeiros ali não seria motivado por algum tipo de desforra do feiticeiro contra a vítima que lhe negou algo, mas pelo comando de araras canibais que, de sua morada no céu, conferem poderes de agressão e cura aos homens, exigindo em troca sangue humano (Wilbert 2004). Mesmo neste caso, em que não se verifica uma ressonância imediata entre motivação, a técnica e a sociologia do feitiço, algum tipo de conexão parece haver entre feitiçaria, bens pessoais e expectativas relacionadas a relações entre próximos.

${ }^{4}$ Como se verá, a distinção xinguana entre formas de agressão mágica e práticas curativas justifica aqui o uso do termo "feitiçaria" em lugar de expressões como "xamanismo negro", "xamanismo agressivo" etc.

${ }^{5} \mathrm{O}$ termo 'ó corresponde ao volume ou torso de uma pessoa ou objeto, enquanto 'ang designa seu duplo ou sombra. No sentido de sombra, todo objeto pode ter uma 'ang, mas quando se trata de uma pessoa, a 'ang se refere àquilo que se desprende 
dela em sonhos, indo passear e encontrando-se com as 'ang de outras pessoas ou coisas e, na morte, tornando-se 'ang ut, "alma penada" (lit. ex-alma/sombra). Não creio ser verdadeiro que os Aweti pensem em 'ó e 'ang como componentes da pessoa, partes que se combinam formando um todo. Ainda que a noção de 'õ pareça corresponder de fato a um substrato material, a 'ang não seria pensada como uma alma que se soma ao primeiro, mas sim como uma qualidade de exteriorização ou multiplicação do ente: é aquilo que, descolando-se dele, pode viver entre outros, animais, espíritos ou mortos. O processo de "recuperar" a 'ang que se desprendeu do corpo através de um tratamento xamânico poderia ser entendido como um controle dessa potência. Ou seja, não se pensa na 'ang como um componente do vivente a não ser em contextos em que ele está, temporária ou permanentemente, entre outros. Ver, para uma discussão sobre a noção de alma como princípio de exterioridade em outro caso tupi, Lima (1996:29).

${ }^{6} \mathrm{O}$ procedimento pode ser bastante mais complicado que uma simples sucção, envolvendo rezas (kewere) e, nos casos mais graves, um ritual secreto realizado por um grupo de xamãs para atrair o kat agressor e lhe oferecer comida em troca do duplo do doente, procedimento considerado complexo e perigoso pelos xamãs aweti.

${ }^{7}$ Alguns aweti notaram a existência de uma infusão vegetal que poderia ajudar na extração de uma flecha tupiat, mas sua fórmula pouco conhecida só pode ser adquirida mediante caros pagamentos: muitos conhecimentos de tratamentos com vegetais são karaty, "coisa da qual se tem ciúme", objeto de sovinice. Além disso, a eficácia da infusão contrafeiticeira não é garantida.

${ }^{8}$ A existência de um xamanismo agressivo entre os povos caribe xinguanos foi, no entanto, reportada a Franchetto (2011, comunicação pessoal), outra indicação de que a feitiçaria ali não pode ser entendida fora de um sistema amazônico de transformações.

${ }^{9} \mathrm{O}$ fato de a feitiçaria xinguana envolver simultaneamente uma técnica e certa habilidade corporal, mas sobretudo uma técnica de construção corporal específica, nos impossibilitaria de classificá-la como "feitiçaria" ou "bruxaria", nos termos da clássica oposição proposta por Evans-Pritchard (2005 [1937]) a partir do caso azande. Como se vê, ademais, todo corpo xinguano é um corpo tecnicamente construído, não mais nem menos que o corpo do feiticeiro ou do xamã, o que me leva a discordar de Barcelos Neto (2006) quando afirma que o feiticeiro xinguano é um não humano. Todo xinguano o é, em alguma medida.

${ }^{10}$ Apesar de apenas homens poderem se tornar especialistas de feitiço no alto Xingu, os malefícios podem ser contratados tanto por homens quanto por mulheres. A feitiçaria de vingança atinge não apenas o executor de uma morte, mas também seu mandante.

${ }^{11}$ Provavelmente o termo é formado pelo substantivo mo'a(t), humano, gente, somado ao causativo $-k a$. 
${ }^{12}$ Para outros sentidos da ação mo'aka, ver Vanzolini (2011b): vale apenas notar que os múltiplos contextos de aplicação deste verbo dão pistas importantes sobre o campo semântico recoberto pelo termo mo'at, que delineia uma estreita conexão entre noções aparentemente díspares, como as de vivente, parente, especialista ritual (té itat, lit. "dono do canto") e chefe (morekwat).

${ }^{13}$ Os Aweti contam que os feiticeiros xinguanos costumam usar roupas (-epit) sobrenaturais para se locomoverem de noite e atacar pessoas de aldeias distantes. As roupas animais xinguanas são entidades vivas que, uma vez encontradas no mato, podem ser domesticadas por qualquer homem através de fumigações com tabaco, e uma vez capturadas, devem ser mantidas num abrigo no mato, como um animal de estimação (-puza). A domesticação de roupas animais, no entanto, parece ser bem mais rara que a feitiçaria. No entanto, é significativo que, mesmo sem aludirem à posse de uma roupa animal, os Aweti afirmem que um feiticeiro se revela para sua vítima, em sonho, sob a forma de um jaguar. Isto sugere que a imagem assumida pelo feiticeiro não indica apenas a posse de habilidades de locomoção especiais, mas sobretudo sua distância em relação à vítima, seja porque vem de longe, seja porque, vivendo perto, trata um parente como presa, atuando, portanto, como um jaguar. A distância geográfica do feiticeiro que usa uma roupa animal para atacar uma pessoa que vive longe seria assim apenas um caso especial e raro da distância perspectiva que a feitiçaria supõe (e impõe) entre feiticeiro e vítima.

${ }^{14}$ Quarup (em aweti: kwaryp) é o nome aportuguesado pelo qual ficou conhecida na literatura a principal cerimônia intercomunitária xinguana, um rito de segundas exéquias do qual participam todos os grupos da região. Segundo me explicaram os Aweti, a festa tem como objetivo o completo desaparecimento do duplo de um falecido, com a viagem definitiva de sua alma para a aldeia dos mortos no céu (mo'apytewetu, verbo cuja tradução provavelmente seria "fazer desaparecer"). O ritual possui uma fase intracomunitária que dura vários meses, e termina com a reunião de todos ou quase todos os grupos xinguanos na aldeia anfitriã, ao longo de uma noite e na manhã seguinte. A luta conhecida como huka-huka (aweti: towa'apitu) entre membros de comunidades distintas marca o fechamento da festa, assim como de todos os rituais intercomunitários xinguanos, e mesmo das visitas entre pessoas de comunidades distintas não estreitamente aparentadas. Para uma etnografia do ritual, ver Guerreiro (2012).

${ }^{15}$ Fatos que também se aplicam aos torneios regionais de futebol.

${ }^{16}$ Entre os Kisêdje, uma modalidade de feitiçaria comumente utilizada tem por objetivo atrair inimigos para atacarem a aldeia do próprio feiticeiro (Coelho de Souza 2011, comunicação pessoal), uma forma de malefício que consiste, como na feitiçaria yanomami, na dupla internalização do inimigo: porque aos inimigos conhecidos é dado acesso de entrada ao grupo da vítima, e porque o idealizador do malefício é um inimigo interno.

${ }^{17}$ Talvez o ponto mais relevante para uma definição da máquina de guerra deleuze-guattariana seja sua diferenciação da guerra propriamente dita: “Dado que na 
guerra (com ou sem batalha) propõe-se o aniquilamento ou a capitulação de forças inimigas, a máquina de guerra não tem por objeto necessariamente a guerra [...]. Porém, mais geralmente, vimos que a máquina de guerra era a invenção nômade, porque era, na sua essência, o elemento constituinte do espaço liso, da ocupação desse espaço, do deslocamento nesse espaço, e da composição correspondente dos homens [...]. Se a guerra decorre necessariamente da máquina de guerra, é porque esta se choca necessariamente contra os Estados e as cidades, bem como contra as forças (de estriagem) que se opõem ao objeto positivo [...]" (Deleuze \& Guattari 1997 [1980]:102). A máquina de guerra, portanto, pode redundar em guerra contra as formações estatais, às quais se opõem por princípio, ou mesmo ser capturada pelos aparelhos de Estado, que tentarão discipliná-la sob a forma de um órgão militar. O que a define, no entanto, é sua oposição à fixação de ordens hierárquicas, estruturadas, identitárias (seu impulso de ampliação do espaço liso, não marcado por divisões e fronteiras) - suas oposição e exterioridade em relação à ordem do Estado.

${ }^{18}$ Não há pacificação sem produção da violência pois, como afirma Viveiros de Castro, "não há relação sem diferenciação" (2002:422-423), frase que devemos entender em dois sentidos: em primeiro lugar, porque se a diferença é, como argumenta o autor, a forma da relação a partir da qual a identidade é construída, toda relação implica um resíduo de diferença; mas a relação envolve diferenciação também porque a construção de laços de parentesco implica uma produção intencional de diferença entre grupos, à medida que cria relações de identidade interna para cada grupo de parentes. Ver também, nesse sentido, a noção de parentesco analógico em Roy Wagner (1977).

\section{Referências bibliográficas}

ALBERT, Bruce. 1985. Temps du sang, temps de cendres. Représentations de la maladie, système rituel et espace politique chezles Yanomami du sud-est (Amazonie brésilenne). Tese de Doutorado, Laboratoire d'Ethnologie et de Sociologie Comparative, Paris, Université de Paris X.

BARBOSA, Gustavo B. 2005. "A socialidade contra o Estado: a antropologia de Pierre Clastres". Revista de Antropologia, 47(2):529-576.

BARCELOS NETO, Aristóteles. 2004. Apapaatai: rituais de máscaras no Alto Xingu. Tese de Doutorado em Antro- pologia Social, São Paulo, Universidade de São Paulo.

· 2006. "De divinações xamânicas e acusações de feitiçaria: imagens Wauja de agência letal". Mana. Estudos de Antropologia Social, 12(2):285-313.

BASSO, Ellen. 1995. The last cannibals: a south american oral history. Austin: University of Texas Press.

BASTOS, Rafael J. de M. 1984/1985. “O 'payemeramaraka' kamayurá uma contribuição à etnografia do xamanismo do alto Xingu". Revista de Antropologia, 27/28:139-177. 
1987/88/89. “Exegeses yawalapití e kamayurá da criação do parque indígena do Xingu e a invenção da saga dos irmãos Villas Boas". Revista de Antropologia, 30:391-426.

- 1989. A Festa da Jaguatirica: uma partitura crítico-interpretativa. Tese de Doutorado, São Paulo, Universidade de São Paulo.

BETTS, La Vera. 1981. Dicionário parintintin-português - português-parintintin. Brasília, DF: Summer Institute of Linguistics.

BOUDIN, Max Henri. 1966. Dicionário tupi moderno (dialeto tembé-tenetehara do alto rio Gurupi). São Paulo: Faculdade de Filosofia, Ciências e Letras de Presidente Prudente/ Governo do Estado de São Paulo.

CHAUMEIL, Jean Pierre. 1983. Voir, savoir, pouvoir. Le chamanisme chez les Yagua du Nord-Est péruvien. Paris: Éditions de L'École des Hautes Études en Sciences Socieales.

Clastres, Pierre. 2003 [1974]. A sociedade contra o Estado. São Paulo: Cosac \& Naify.

_ 2004 [1977]. Arqueologia da violência: pesquisas de antropologia política. São Paulo: Cosac \& Naify.

COELHO DE SOUZA, Marcela S. 2001. "Virando gente: notas a uma história aweti". In: B. Franchetto \& $\mathrm{M}$. Heckenberger (orgs.), Os povos do Alto Xingu: história e cultura. Rio de Janeiro: UFRJ. pp. 358-400.

DELEUZE, Gilles \& GUATTARI, Félix. 1996 [1980]. "9. 1933 - Micropolítica e segmentaridade". In: Mil platôs. Capitalismo e esquizofrenia. vol. 3. Tradução de A. Guerra Neto, A. L. Oliveira, L. C. Leão e S. Rolnik. Rio de Janeiro: Editora 34. Vol. 3. pp. 76-106. . 1997 [1980]. "12. 1227 - Tratado de nomadologia: a máquina de guerra". In: Mil platôs. Capitalismo e esquizofrenia. vol. 5. Tradução de Peter
Pál Pelbart. Rio de Janeiro: Editora 34. pp. 7-96.

DOLE, Gertrude. 1964. "Shamanism and political control among the Kuikuro". In: Hans Becker (ed.), Beiträge zur Völkerkunde Südamerikas. Hannover, Druck: Munstermann-Druck GMBH. pp. 53-62.

. 1976. "Anarchy without chaos: alternatives to political control among the Kuikuro". In: M. J. Swartz (ed.), Political anthropology. Chicago: Aldine. pp. 73-88.

DOUGLAS, Mary. 1970. "Introduction: thirty years of witchcraft, oracles and magic". In: Witchcraft. Confessions and accusations. London: Tavistock Publications. pp. 257-275.

DRUDE, Sebastian. 2006. "On the position of the Awetí language in the Tupí Family". In: Dietrich Wolf \& Symeonidis Haralambos (eds,), Guaraní y Mawetí-Tupí-Guaraní: estudios históricos y descriptivos sobre una familia linguística de América del Sur. Münster etc.: Lit Verlag. pp.11-45.

EVANS-PRITCHARD， Edward E. 2005 [1937]. Bruxaria, oráculos e magia entre os Azande. Rio de Janeiro: Zahar (Versão condensada por Eva Gillies, traduzida por Eduardo Viveiros de Castro).

FAUSTO, Carlos. 1999. "Of enemies and pets: warfare and shamanism in Amazonia". American Ethnologist, 26(4):933-956.

. 2001. Inimigos fiéis. História, guerra e xamanismo na Amazônia. São Paulo: Editora da Universidade de São Paulo.

FIGUEIREDO, Marina Vanzolini. 2010. A flecha dos ciúmes: o parentesco e seu avesso entre os Aweti do Alto Xingu. Tese de Doutorado, Rio de Janeiro, PPGAS/MN/UFRJ.

FRANCHETTO, Bruna \& HECKENBERGER, Michael (orgs.). 2001. Os povos do 
Alto Xingu. História e cultura. Rio de Janeiro: UFRJ.

GALLOIS, Dominique. 1996. "Xamanismo waiãpi: nos caminhos invisíveis, a relação i-paie". In: J. M. Langdon (org.), Xamanismo no Brasil: novas perspectivas. Florianópolis: Editora da UFSC. pp. 39-74.

GALVÃO, Eduardo. 1979 [1953]. "Cultura e sistema de parentesco das tribos do alto rio Xingu". In: Encontro de sociedades. Índios e brancos no Brasil. Rio de Janeiro: Paz e Terra. pp. 73-119.

GREGOR, Thomas. 1977. Mehinaku: the drama of daily life in a Brazilian Indian village. Chicago: The University of Chicago Press.

- 1992. "Uneasy peace: intertribal relations in Brazil's Upper Xingu". In: J. Haas (ed.), The anthropology of war. Nova York: The Cambridge University Press. pp. 105-125.

GUERREIRO, Antônio. 2012. Ancestrais e suas sombras. Uma etnografia da chefia kalapalo e seu ritual mortuário. Tese de Doutorado, Brasília, UnB.

KAPFERER, Bruce. 1997. The feast of the sorcerer. Practices of conciousness and power. Chicago e Londres: The University of Chicago Press.

LAGROU, Elsje. 2004. "Sorcery and shamanism in Cashinaua discourse and praxis, Purus River, Brazil". In: N. L. Whitehead \& R. Wright (eds.), In darkness and secrecy. The anthropology of assault sorcery and dark shamanism in Amazonia. Durham \& London: Duke University Press. pp. 244-271.

LIMA, Tania Stolze. 1996. "O dois e seu múltiplo: reflexões sobre o perspectivismo em uma cosmologia tupi". Mana. Estudos de Antropologia Social, 2(2):21-47.

MAYBURY-LEWIS, David. 1974 [1967]. Akwě-Shavante society. Nova York: Oxford University Press.
MENGET, Patrick. 2001 [1977]. Em nome dos outros. Classificação das relações sociais entre os Txicáo do Alto Xingu. Lisboa: Museu Nacional de Etnologia Assírio e Alvim.

MIDDLETON, John \& WINTER, E. H. (eds.). 1963. Witchcraft and sorcery in East Africa. London: Routledge \& Kegan Paul.

OVERING-KAPLAN, Joanna. 1986. “Images of cannibalism, death and domination in a 'non-violent' society". Journal de la Société des Américanistes, 72:133156.

PISSOLATO, E. 2006. A duração da pessoa. Mobilidade, parentesco e xamanismo mbya (guarani). Tese de Doutorado, Rio de Janeiro, PPGAS/MN/UFRJ.

RIVIÈRE, Peter. 1970. "Factions and exclusions in two South American village systems". In: Mary Douglas (ed.), Witchcraft. Confessions and accusations. London: Tavistock Publications. pp 245-255.

SCHADEN, E. 1974. Aspectos fundamentais da cultura guarani. São Paulo: Edusp.

SEEGER, Anthony. 1981. Nature and society in Central Brazil. Cambridge: Harvard University Press.

- 1987. Why Suyá sing. A musical anthropology of an Amazonian people. Cambridge: Cambridge University Press.

STASCH, R. 2001. "Giving up homicide: Korowai experience of witches and police (West Papua)". Oceania, 72(1):33-52.

. 2009. Society of others: kinship and mourning in a West Papuan place. Los Angeles: University of California Press. STEINEN, Karl Von den. 1940. "Entre os aborígenes do Brasil Central". Revista do Arquivo Municipal. Separata.

SZTUTMAN, Renato. 2005. O profeta e o principal. A ação política ameríndia 
e seus personagens. Tese de Doutorado, São Paulo, Universidade de São Paulo.

TAYLOR, Anne-Christine. 1994. "Les bons ennemis et les mauvais parents: le traitement symbolique de l'alliance dans les rituels de chasse aux têtes des Jivaros de l'Equateur". In: E. Copet \& H. Héritier-Augé (eds.), Les complexités de l'alliance IV (économie, politique et fondements symboliques de l'alliance). Paris: Archives Contemporaines. pp. 71-105.

VANZOLINI, Marina. 2011a. "O parentesco pervertido: notas sobre a feitiçaria no Alto Xingu". In: E. Coffaci de Lima \& L. Córdoba (orgs.), Os outros dos outros: relações interétnicas na etnologia sulamericana. Curitiba: UFPR. pp. 211-223.

. 2011b. "Eleições na aldeia ou, o Alto Xingu contra o Estado?". Anuário Antropológico, 2010(1):31-54.

VILAÇA, Aparecida. 1992. Comendo como gente. Formas do canibalismo wari'. Rio de Janeiro: Editora da Universidade Federal do Rio de Janeiro.

VIVEIROS DE CASTRO, Eduardo B. 1986. Araweté, os deuses canibais. Rio de Janeiro: Zahar/Anpocs.

. 1993. "Alguns aspectos da afinidade no dravidianato amazônico". In: M. Carneiro da Cunha \& E. B. Viveiros de Castro (eds.), Amazônia: etnologia e história indígena. São Paulo: NHIIUSP/Fapesp. pp. 149-210.

• 2002. "Atualização e contraefetuação do virtual: o processo do parentesco". In: A inconstância da alma selvagem. São Paulo: Cosac \& Naify. pp. 401-456.

WAGNER. 1977. "Analogic kinship: a Daribi example". American Ethnologist, 4(4):623-642.

WHITEHEAD, N. L. \& WRIGHT, R. (eds.). 2004. In darkness and secrecy. The an- thropology of assault sorcery and dark shamanism in Amazonia. Durham \& London: Duke University Press.

WILBERT, Johannes. 2004. "The order of dark shamans among the Warao". In: N. L. Whitehead \& R. Wright (eds.), In darkness and secrecy. The anthropology of assault sorcery and dark shamanism in Amazonia. Durham \& London: Duke University Press. pp. 21-50.

WRIGHT, Robin. 2004. "The wicked and the wise men: witches and prophets in the history of the Northwest Amazon". In: N. L. Whitehead \& R. Wright (eds.), In darkness and secrecy. The anthropology of assault sorcery and dark shamanism in Amazonia. Durham \& London: Duke University Press. pp. 82-108.

ZARUR, George. 1975. Parentesco, ritual e economia no Alto Xingu. Brasília: Funai. 


\section{Resumo}

Baseado em uma pesquisa de campo com os Aweti, grupo tupi do alto Xingu, o artigo propõe uma reflexão sobre as particularidades da agressão mágica xinguana no cenário amazônico, relacionando técnicas, campos de incidência e efeitos políticos de tais práticas. Contrariando uma imagem corrente na etnologia regional, os xinguanos sempre identificam a fonte de seus maiores sofrimentos com a ação de pessoas bastante próximas, frequentemente coaldeãos da vítima, e sempre outros xinguanos, isto é, integrantes do que Ellen Basso denominou de "comunidade moral" xinguana: um conjunto multiétnico de aliados que se define, idealmente, pela abdicação da violência entre si. A hipótese central deste trabalho é que a feitiçaria xinguana deveria ser pensada como parte de um mecanismo de produção de inimizade que, operando a partir das relações cotidianas, faz com que o esforço histórico de produção de identidade comunitária pareça nunca se completar.

Palavras-chave Alto Xingu, Feitiçaria, Xamanismo, Guerra, Política ameríndia.

\section{Abstract}

Based on field research with the Aweti, a Tupi speaking group from the Upper Xingu, this article presents an analysis of the singularities of Xinguano magical aggression in an Amazonian context, by comparing the techniques, sociology and political effects of these practices. Contrary to the prevalent image of the anthropology of the region, the Xinguanos always identify the source of their greatest suffering in acts of people with whom they share intimate relations, frequently the victim's co-villagers and always other Xinguanos; that is, members of what Ellen Basso has called the Xinguano moral community: a multiethnic group of allies defined, ideally, by the abdication of internal violence. The central hypothesis of this work is that Xinguano sorcery should be considered a part of mechanisms that produce enmity out of ordinary relations, meaning that the continuous effort to produce identity is never entirely complete.

Key words Upper Xingu, Sorcery, Shamanism, Warfare, Amerindian politics. 